Check for updates

Washington, DC, USA

thackerpd@gmail.com

Cite this as: BMJ 2020;370:m3430

http://dx.doi.org/10.1136/bmj.m3430

Published: 08 September 2020

\section{The US politicisation of the pandemic: Raul Grijalva on masks, BAME, and covid-19}

\author{
Democratic congressman Raul Grijalva infamously caught covid-19 after attending a Black Lives \\ Matter hearing with a Republican who downplayed wearing a mask. He speaks to Paul D Thacker \\ about the politicisation of the pandemic and disproportionate health burdens affecting minority \\ groups
}

\section{Paul D Thacker}

It was an incident that seemed to epitomise the state of affairs in the US. During the last week of July, Congressman Raul Grijalva, a Democrat from Arizona, chaired a hearing of the House Committee on Natural Resources to examine police activity against people involved in a Black Lives Matter protest. Also attending was Republican congressman Louie Gohmert who had long downplayed the dangers of covid-19 and seldom wore a mask.

The next day, Gohmert tested positive for the virus. Grijalva was also later found positive and had to go into quarantine for 14 days, suffering minor symptoms.

The son of Mexican immigrants, Raul Grijalva has long campaigned for minorities-who are most affected by the virus in the US-and is now focused on the disproportionate health effects that living next to industrial pollution can have on them. Research has indicated that the huge impact of covid-19 on minority groups may in part be because of pre-existing factors caused by living in areas with high exposure to industrial chemicals. ${ }^{1}$

Grijalva is championing the Environmental Justice for All Act, a bill he introduced to Congress weeks before the pandemic hit the US. If passed, the bill would uphold the right of all to clean air and drinking water irrespective of race, origin, or income level. Among other actions, it would authorise \$75m ( $€ 57 \mathrm{~m}$; $€ 63 \mathrm{~m}$ ) to support projects tackling environmental and public health problems. ${ }^{2}$

\section{How did you end up in Congress?}

“It's been a bit of an odyssey, but I think I'm pretty reflective of the people that live in my district. I'm a first generation American. My parents were immigrants from Mexico. I sought elective office on a school board when I was very young-21. I was then a social worker and on the county board of supervisors. I got elected to Congress in 2002 and ended up being chairman of the Natural Resources Committee.

"The people of my district are hardworking, but often on low incomes. Racially and economically, we are a vulnerable district in terms of poverty and unemployment. We are on the border with Mexico, and we have had to deal with all the problems that President Trump has generated on the border in terms of immigration, migrants, and refugees. And we have a strong environmental ethic that is very important to people."

\section{You had covid-19. What happened?}

"Before I left my home in Tucson, Arizona, I went to a clinic to encourage other people to do the test. It came up negative.

"I got to the capital and Congressman Gohmert was part of this oversight hearing, sometimes using and sometimes not using his mask. He then tested positive for covid-19 when he tried to get on a plane with the president to go to some event.

"When I saw that-and knowing he had been sitting less than six feet away from me at the hearing-I went and got tested and came up positive. Can I definitively say he's the cause? No. But I can definitively say that he was the only one running around without a mask in the capital that I dealt with.”

\section{How did masks become such a political matter?}

"There's a group of members of Congress that are aligned with President Trump who were politicising the wearing of face masks, social distancing, and any of the preventive steps necessary to control the spread of this very dangerous virus. They've made it a political statement. So, on occasion, they don't wear masks and don't follow the guidelines that have been established.

"The president politicised this. He wanted to minimise the effect of this pandemic based on whatever political calculations and re-election considerations he might have-'This will go away. Not a big deal.' And to some extent, he is continuing to do that.

"The more extremist elements that support him took it up as a political matter-that this is about individual rights, that the virus is a hoax, and that you don't need masks. By politicising it, by ignoring science, by ignoring facts, it essentially politicised prevention tactics. This made the situation worse and added to the misery we are experiencing.

"The president encouraged Gohmert and he encouraged other groups to make this a cause. And it probably increased the spread of the virus."

You have a lot of the risk factors for covid-19: you're Hispanic, you're over 70, you're 


\section{overweight, you're a smoker. How did you feel when you} got a positive test result?

"I had two overwhelming feelings. First, I was scared-anybody that says that they weren't scared as a result of testing positive is lying. I was scared. And then I was very angry that someone would be so selfish as to unnecessarily risk exposing not only me, but the congressional staff that have to interact with them at a meeting. I'm not scared now, but I'm still angry.

"The pre-existing conditions in poor and minority communities that affect covid-19 severity have been there for decades. And those pre-existing conditions include poverty, lack of quality schools, lack of healthcare, and a lack of jobs-or at least jobs that have a path that is going to make your situation more sustainable and better for your family.

"And then you have the cumulative effect of one decision after another being made that brings bad air, bad water, and pollution next to or on top of these communities because of the zoning decisions and the permitting decisions that were made by local, state, or federal agencies. That's why you have these higher incidences of cancer, higher incidences of asthma, heart disease, and the list goes on.

"What the coronavirus did is expose these pre-existing conditions. Many of us knew about this, but the pandemic brought it to the attention of a much wider range of people. To some people, it was new. And to others it was an affirmation."

\section{How will the Environmental Justice for All Act help?}

"We wrote a comprehensive bill. The strategy was to start at the bottom and work directly with affected communities, meaning communities of colour and poor communities across the country.

"When covid-19 hit, the problems of systemic racism and neglect and discrimination around social justice and criminal justice matters became prominent. The pandemic exposed racial disparities. We have a bill that has a systemic solution to a systemic problem.”

Commissioned, not peer reviewed

Competing interests: I have read and understood BMJ policy on declaration of interests and have no relevant interests to declare.

1 Washington HA. How environmental racism is fuelling the coronavirus pandemic. Nature. 19 May 2020. How environmental racism is fuelling the coronavirus pandemic. www.nature.com/articles/d41586-020-01453-y.

2 Nicholson-Choice MN. Environmental Justice for All Act introduced in Senate. National Law Review. 3 August 2020. www.natlawreview.com/article/environmental-justice-all-act-introduced-ussenate. 